\title{
Immunomodulatory mechanisms of lactobacilli
}

Jerry M Wells

From 10th Symposium on Lactic Acid Bacterium

Egmond aan Zee, the Netherlands. 28 August - 1 September 2011

\begin{abstract}
Over the past decade it has become clear that lactobacilli and other probiotic and commensal organisms can interact with mucosal immune cells or epithelial cells lining the mucosa to modulate specific functions of the mucosal immune system. The most well understood signalling mechanisms involve the innate pattern recognition receptors such as Toll-like receptors, nucleotide oligomerization domain-like receptors and C-type lectin receptors. Binding of microbe-associated molecular patterns with these receptors can activate antigen presenting cells and modulate their function through the expression of surface receptors, secreted cytokines and chemokines. In vitro the cytokine response of human peripheral blood mononuclear cells and dendritic cells to lactobacilli can be strikingly different depending on both the bacterial species and the strain. Several factors have been identified in lactobacilli that influence the immune response in vitro and in vivo including cell surface carbohydrates, enzymes modifying the structure of lipoteichoic acids and metabolites. In mice mechanistic studies point to a role for the homeostatic control of inducible T regulatory cells in the mucosal tissues as one possible immunomodulatory mechanism. Increasing evidence also suggests that induction of epithelial signalling by intestinal lactobacilli can modulate barrier functions, defensin production and regulate inflammatory signalling. Other probiotic mechanisms include modulation of the T cell effector subsets, enhancement of humoral immunity and interactions with the epithelial-associated dendritic cells and macrophages. A major challenge for the future will be to gain more knowledge about the interactions occurring between lactobacilli and the host in vivo and to understand the molecular basis of innate signalling in response to whole bacteria which trigger multiple signalling pathways.
\end{abstract}

\section{Introduction}

The genus Lactobacillus comprises a large heterogeneous group of low-G+C Gram-positive, non-sporulating, and facultative anaerobes [1]. Taxonomically, the genus Lactobacillus belongs to the phylum Firmicutes, class Bacilli, order Lactobacillales, family Lactobacillaceae. Currently the genus Lactobacillus contains 154 species of which more than 20 have been sequenced. They have limited biosynthetic abilities, and require preformed amino acids, B vitamins, purines, pyrimidines and (usually) a sugar as a carbon and energy source which is fermented to produce lactic acid as a common end product. These nutritional requirements restrict their habitats to those in which the required compounds are abundant. Nevertheless, the lactobacilli occupy a

\footnotetext{
Correspondence: jerry.wells@wur.nl
}

Host-Microbe-Interactomics, University of Wageningen, Animal Sciences

Department, P.O. Box 338, 6700 AH, Wageningen, The Netherlands

Full list of author information is available at the end of the article variety of niches including milk, plant surfaces, and the gastrointestinal tract of humans and other animals. Several food-associated species of lactobacilli have an excellent safety profile and a "generally-regarded-as-safe" status in the food industry due to their long history in food fermentation and human consumption.

Lactobacilli are found in low numbers in the small intestine of adults but some may originate from fermented foods or the oral cavity which is home to several autochthonous species. In adult faeces they form only a minor component of the microbiota ranging from 0.01 to $0.6 \%$ of total counts [2]. In infants lactobacilli are present in the faeces in variable amounts ranging from $10^{5}$ to $10^{8} \mathrm{CFU} / \mathrm{g}$ with $L$. salivarius, L. rhamnosus, and L. paracasei being common species [3]. In addition lactobacilli are dominant members of the human vaginal microbiota where they play a protective role against urogenital infections [4].
C Biomed Central

(c) 2011 Wells; licensee BioMed Central Ltd. This is an open access article distributed under the terms of the Creative Commons Attribution License (http://creativecommons.org/licenses/by/2.0), which permits unrestricted use, distribution, and reproduction in any medium, provided the original work is properly cited. 
Numerous probiotic studies with different strains of Lactobacillus have been performed in humans and murine models to investigate their probiotic potential. While some clinical studies have been negative or inconclusive [5-8] others have shown positive results (see e.g. [9-14]). The lactobacilli have given significant and promising results in treating acute infectious diarrhoea and in the prevention of antibiotic-associated diarrhoea in human clinical trials [10]. The use of probiotic lactobacilli in the treatment and prevention of allergic diseases and in the treatment of allergic rhinitis/asthma has been reviewed recently $[15,16]$. Most clinical studies on allergy have been performed with Lactobacillus rhamnosus GG (LGG) which was shown to prevent atopic eczema or dermatitis $[13,14]$. Subsequent studies on the use of LGG in the treatment of atopic eczema suggested a therapeutic effect $[9,11,12]$, whereas more recent studies show no therapeutic or preventative effects benefits in the development of sensitization and atopic disease, particularly in infants with atopic dermatitis [6-8]. These contrasting results probably reflect the inherent complexity of the allergic syndrome, and differences in the clinical set-up e.g. different target populations, countries, intervention schemes and the formulation of LGG used in the study [15]. Overall there is encouraging evidence that specific lactobacilli probiotics are valuable in the prevention and treatment of different diseases but their successful application would benefit greatly from a better understanding of the mechanisms of probiotic action in clinical studies. The purpose of this review is to discuss the molecular basis for immune recognition of lactobacilli by the host and to highlight the possible mechanisms leading to different strain-dependent host responses. A detailed analysis of results of probiotic studies in different mouse models and clinical studies is beyond the scope of this review but the immunomodulatory mechanisms of probiotic lactobacilli in vivo are discussed.

\section{Immune recognition of lactobacilli}

Lactobacilli can elicit innate and adaptive immune responses in the host via binding to pattern recognition receptors (PRR) expressed on immune cells and many other tissues including the intestinal epithelium. PRR recognize conserved molecular structures known as microbe-associated molecular patterns (MAMPs) and signal to induce the production of cytokines, chemokines and other innate effectors (recently reviewed [17-19]). These signalling receptors can be divided into three families; Toll-like receptors (TLRs), retinoic acid inducible gene I (RIG-I)-like receptors that recognize viral RNAs (RLRs) and nucleotide oligomerization domain-like (NOD) receptors (NLRs). The TLR family is the best characterized and 10 TLRs have been identified in humans and 12 in mice [19]. For TLRs it has been shown that MAMP binding and specificity is achieved through the arrangement and sequence variation in the extracellular leucine-rich repeat (LRR) domains. Dimerization of the TLR and the highly conserved intracellular Toll-interleukin 1 receptor (TIR) domains leads to the recruitment of adaptor molecules such as myeloid differentiation primary response gene 88 (MyD88), toll-interleukin 1 receptor (TIR) domain containing adaptor protein (TIRAP) and TIR-domaincontaining adapter-inducing interferon- $\beta$ (TRIF) to initiate the signalling cascade. Each PRR recognizes a specific molecular pattern and can be expressed on the cell surface, in intracellular compartments or in the cytosol (Table 1). TLR1, 2, 4, 5, 6 and 11 recognize mainly microbial membrane components and are expressed on the cell surface, TLR3, 7, 8 and 9 recognize nucleic acids of bacterial and viral origin and are expressed in intracellular compartments such as the endoplasmic reticulum, endosomes, lysosomes and endolysosome (Table 1). In epithelial cells TLR9 is expressed on the cell surface and intracellularly.

TLR signalling pathways have been reviewed in detail recently [19] and except for TLR3 involve recruitment of MyD88, which in turn activates the mitogen-activated protein kinase (MAPK) pathway and the nuclear factor $\kappa \mathrm{B}(\mathrm{NF}-\kappa \mathrm{B})$ pathway signalling cascades [20] (Fig 1). TLR3 utilizes the adaptor protein TRIF leading to the expression of type 1 interferons. In addition this adaptor serves as an alternative adaptor to MyD88 in the TLR4 signalling pathway. The NOD receptors activate the MAPK pathway and the canonical NF- $\kappa \mathrm{B}$ pathway signalling cascades. In an inactivated state, NF- $\kappa \mathrm{B}$ is located in the cytosol as a protein complex with the inhibitory protein $\mathrm{I} \kappa \mathrm{B} \alpha$ but TLR and NLR signalling leads to the phosphorylation of $\mathrm{I} \kappa \mathrm{B} \alpha$, its ubiquitination and degradation by the cell proteasome. Liberated NF$\kappa \mathrm{B}$ then translocates into the nucleus and induces the transcription of specific genes (Fig 1).

PRR signalling pathways play a key role in both the innate and adaptive immune responses, for example by influencing the skewing of naïve $\mathrm{T}$ cells, the regulation of regulatory $\mathrm{T}$ cells and activation of antigen presenting cells (APCs) such as dendritic cells (DCs) and macrophages. DCs are specialized APCs, that regulate both innate and adaptive immunity (recently reviewed [21]) and are found throughout the lamina propria of the intestine as well as in the gut-associated lymphoid tissues such as the Peyer's patches. Most tissue resident DCs are immature and poorly immunogenic due to the low expression of $\mathrm{MHC}$ molecules and co-stimulatory molecules. However, contact with MAMPs or other danger signals induces PRR signalling and activation of the NF- $\kappa \mathrm{B}$ pathway leading to maturation and 
Table 1 PRR, ligands and subcellular localization

\begin{tabular}{llll}
\hline Receptor & Localization & Ligand & Origin of the ligand \\
\hline TLR2 & Cell surface & Lipopeptides & Bacteria \\
& & Lipoproteins & G+ bacteria \\
& & LTA & G+ bacteria \\
TLR2/1 & Cell surface & Triacylated lipopeptide & G-bacteria, mycoplasma \\
TLR2/6 & Cell surface & Diacylated lipopeptides & G+ bacteria, mycoplasma \\
TLR3 & Intracellular compartment & dsRNA & Viruses, virus infected cells \\
TLR4/MD2 & Cell surface, intracellular compartment & LPS & G- bacteria \\
TLR5 & Cell surface & Flagellin protein & Bacteria \\
TLR7 & Intracellular compartment & ssRNA & Viruses \\
TLR8 & Intracellular compartment & ssRNA & Viruses \\
TLR9 & Intracellular compartment, cell surface & DNA & DNA viruses, bacteria \\
TLR11 & Cell surface & Uropathogenic bacterial components & Uropathogenic bacteria \\
NOD1 & Cell cytoplasm & Meso-DAP & PG from G-, some G+, mycobacterium \\
NOD2 & Cell cytoplasm & MDP & PG from G-, G+ bacteria, mycobacterium
\end{tabular}

PG, peptidoglycan; LTA, lipoteichoic acid; LPS, lipopolysaccharide; DAP, diaminopimelic acid; MDP, muramyl dipeptide; G+, Gram positive; G-, Gram negative; ssRNA, single-stranded RNA; dsRNA, double-stranded RNA.

activation. Mature DC express high levels of MHC, costimulatory molecules and cytokines required for antigen presentation and $\mathrm{T}$ cell activation, clonal expansion and differentiation [22]. The levels of cytokines produced by activated DCs are influenced by the nature of the TLR, CLR and NLR stimuli. This has important consequences for the induction of different $\mathrm{T}$ cell subsets and also our understanding of how different strains and species of lactobacilli can differentially modulate the immune response.

In intestinal epithelial cells (IEC), activated NF- $\kappa$ B can induce the production of a broad range of chemokines and cytokines including interleukins (ILs), tumour necrosis factors (TNFs), growth factors and inducible beta-defensins (BDs). These play a key role in maintaining barrier functions and homeostasis (reviewed in [23]). Endocrine, goblet and enterocytes of the intestinal epithelium express a range of PRR to sense the presence of microbes. In the human colon TLR2 and 4 were shown by immunohistochemical techniques to be expressed mainly in the enterocytes lining the crypts [24-26]. In the mouse, immunohistochemical analyses showed that TLR2, TLR4 and TLR5 are localized on both the follicle-associated epithelium (FAE) covering the Peyer's Patches and the epithelium of the small intestinal villi and crypts [27] but TLR4 expression was relatively low. TLR2 is located only on the apical membrane of small intestinal IECs in the mouse and human $[26,27]$. In the intestinal epithelium excessive immune responses to non-pathogens are avoided by several mechanisms: (i) the regulation of TLR expression, (ii). TLR localization, (iii) differential apical and basolateral TLR signalling, (iv) negative feedback regulation of the $\mathrm{NF}-\mathrm{kB}$ pathway and (v) the attenuation of NF- $\kappa \mathrm{B}$ activation by commensal bacteria. These adaptations are part of several overlapping and intertwined mechanisms that maintain homeostasis of inflammatory innate responses in the gut.

\section{Recognition of lactobacilli via TLR2 signalling pathways}

Cell wall components of the lactobacilli can potentially signal through binding to TLR2 in combination with TLR6. Over a decade ago bacterial lipoproteins were shown to recognize TLR2 $[28,29]$. Recognition is mediated through binding of the lipid chains which are post-translationally coupled to a specific $\mathrm{N}$-terminal lipoprotein signal during secretion [30]. In Gram-positive bacteria and Gram-negative bacteria a prolipoprotein diacylglyceryltransferase (Lgt) transfers a diacylglyceride group to the cysteine sulfhydryl group adjacent to the signal peptide cleavage group (Fig 2). Subsequently the signal peptide is cleaved just before the cysteine residue resulting in the addition of two acyl (lipid) chains to the N-terminus of the lipoprotein. The acyl chains anchor the lipoprotein protein in the cytoplasmic membrane. However, in Gram-negative bacteria and mycobacteria which have an outer membrane an apolipoprotein $\mathrm{N}$-acyltransferase (Lnt) enzyme attaches a third acyl group to the amino group of the $\mathrm{N}$-terminal cysteine. This mediates transport of the lipoprotein to the outer membrane (Fig 2). Recent crystallographic structural data on binding of synthetic mimics of the lipoprotein membrane anchors to TLR1 and 2 or TLR2 and 6 have revealed that the diacyl lipid chains added by Lgt bind in a hydrophobic pocket in the extracellular domain of TLR2 (Fig 2). In the case of tri-acylated liopoproteins the third lipid chain interacts with a hydrophobic channel in TLR1 to promote dimerization and 


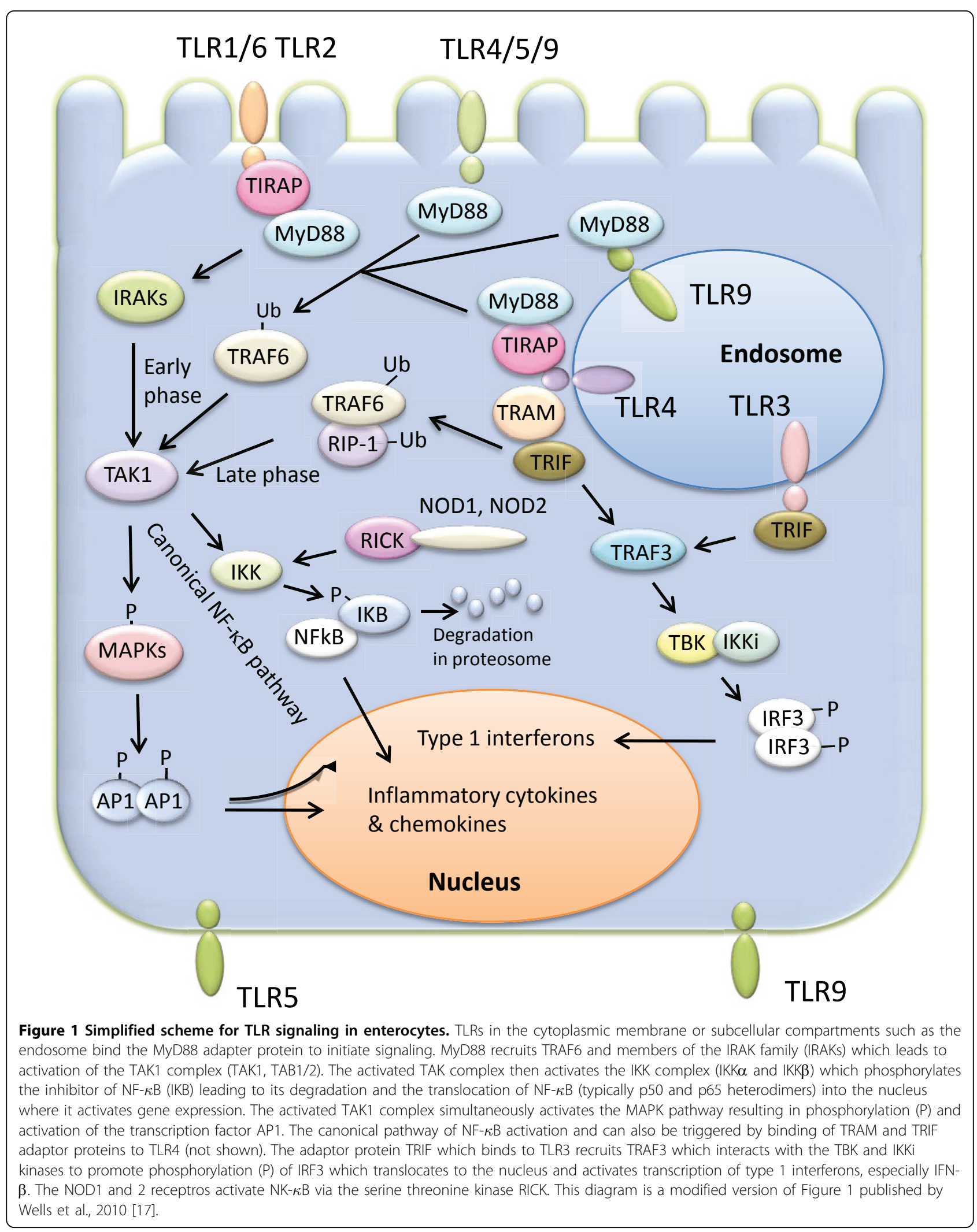



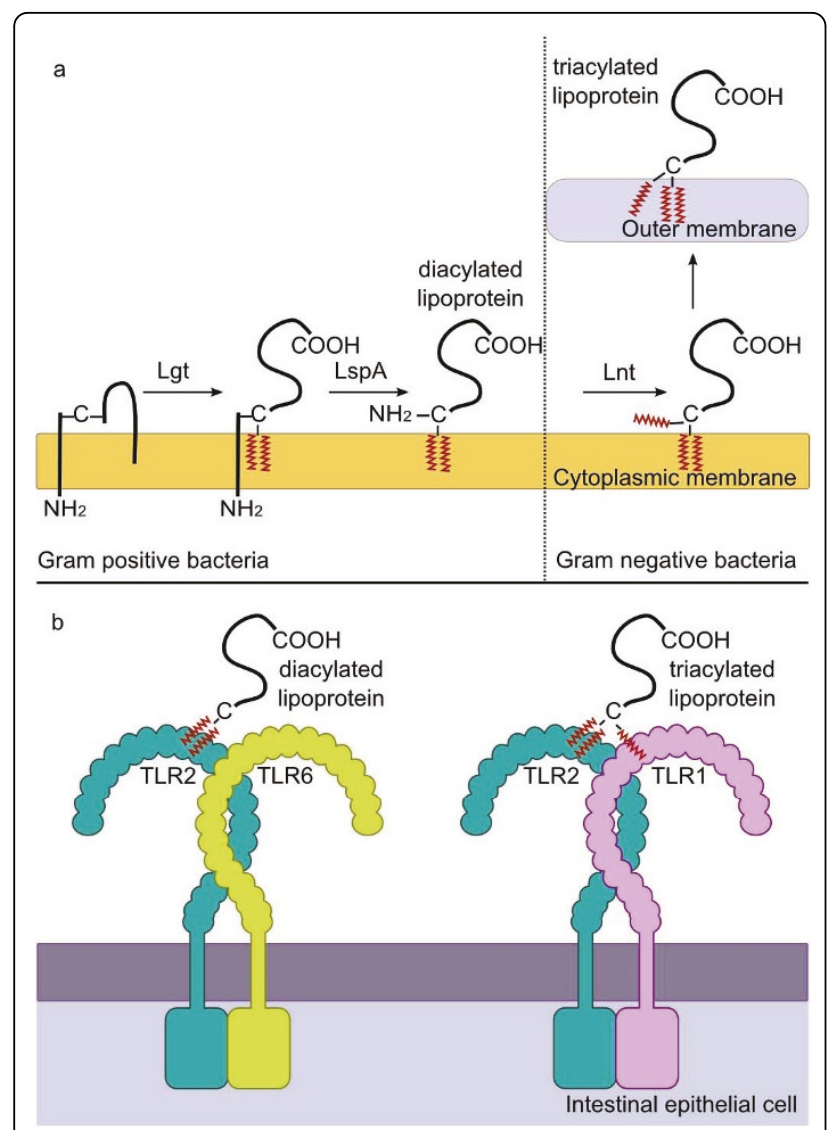

Figure 2 TLR2 recognition of lipoproteins and LTA. Recognition of LTA and lipoproteins is mediated through binding of the lipid chains which anchor these molecules in the membrane. a). All lipoproteins possess a specific N-terminal lipoprotein signal which targets the protein for secretion and post-translational modification. In Gram-positive bacteria and Gram-negative bacteria the Lgt enzyme transfers a diacylglyceride group to the cysteine sulfhydryl group adjacent to the signal peptide cleavage site. Subsequently the signal peptide is cleaved just before the cysteine residue by LspA yielding a mature di-acylated lipoprotein. However, in Gramnegative bacteria and mycobacteria the Lnt enzyme attaches a third acyl group to the amino group of the N-terminal cysteine promoting its transport to the outer membrane. b). The diacyl lipid chains added by Lgt bind in a hydrophobic pocket in the extracellular domain of TLR2 and the head group of the peptide interacts with TLR6 to promote hetero-dimerization and signalling. In the case of tri-acylated lipoproteins the third lipid chain interacts with a hydrophobic channel in TLR1 to promote dimerization and signalling. This diagram is a modified version of Figure 1 published by Schenk et al., 2009 [101].

robust signalling [32]. In the case of TLR6 this hydrophobic channel is blocked preventing its binding to triacylated lipoproteins. Instead specific interactions with other parts of the di-acylated lipoprotein promote dimerization with TLR2 and signalling [31-33]. The coreceptors CD36, CD14 and lipopolysaccharide binding protein contribute to the recognition of LTA and TLR2mediated signalling $[34,35]$. The anionic properties of the WTA and LTA may also contribute to immune signalling through their binding to scavenger receptors such as SRA which has been shown to bind purified LTA [36]. Apart from lipoproteins, TLR2 has been reported to bind the lipid chains anchoring lipoteichoic acid (LTA) in the cytoplasmic membrane of Gram-positive bacteria. In contrast the wall teichoic acids WTA are covalently attached to the peptidoglycan and presumably cannot signal through TLR $2 / 6$ as they lack a lipid anchor. LTAs and WTAs are anionic due to a Dala substitution by the enzymes of the dlt operon. A Dlt- mutant of Lactobacillus plantarum strain NCIMB8826 was found to incorporate much less D-Ala in its TAs than the WT strain [37]. This defect significantly impacted on the immunomodulatory properties of the bacterium, as shown by a reduction in the secretion of proinflammatory cytokines by peripheral blood mononuclear cells and monocytes in co-culture with the dlt mutant and wild type strain [37]. This is also compatible with a study on a minimal synthetic structure of LTA showing that that the D-ala substitution of the polyglycerol backbone amplifies the response to the lipid anchor [38]. Furthermore, the amount of IL-10 produced in co-culture of PBMC with the dlt mutant was significantly increased compared to the parent strain [37]. These differences were shown to be TLR2 dependent implicating the interaction of LTA and D-ala substituted LTA with TLR2 in mediating the different immune responses. In a mouse model of colitis the Dltmutant was significantly more protective than its WT counterpart [37]. In contrast a dltD mutation in $L$. rhamnosus did not significantly alter cytokine production by intestinal epithelial cells and peripheral blood mononuclear cells in comparison to the wild type strain. Nevertheless the L. rhamnosus dlt mutant was more sensitive to anionic detergent, killing by to human betadefensin- 2 and showed altered cell shape, septation and increased rate of autolysis [39]. The reason for the differences between L. plantarum and L. rhamnosus are not clear but may be related to the species and straindependent differences in LTA and WTA composition. For example the cell walls of $L$. rhamnosus and $L$. case $i$ appear to contain only LTA in contrast to other lactobacilli which also contain WTA [39].

Recently deletion of the phosphoglycerol transferase gene that primes the synthesis of bacterial LTA was reported in L. acidophilus strain NCK56 resulting in a strain lacking LTA [40]. Interestingly, the mutant strain NCK2025 down-regulated production of IL-12 and TNF $\alpha$ in co-culture with human monocyte derived dendritic cells but also significantly enhanced IL-10. The DC stimulated with the mutant and wild type strain also differed in their ability to induce proliferation of $\mathrm{T}$ cells isolated from MLN of mice which had been oral fed $L$. 
acidophilus for 4 consecutive days. T-cell proliferation was significantly abrogated in the LTA mutant-treated DCs co-cultured with T cells. Adding anti-IL10 antibody abrogated the suppression of $\mathrm{T}$ cell proliferation by the LTA mutant strain. Thus the $\mathrm{T}$ cell suppression was most likely due to the higher levels of IL-10 produced by $\mathrm{DC}$ cultured with the mutant strain than the wild type [40]. Furthermore, the NCK205 mutant was superior to the wild type strain in preventing dextran sulphate sodium (DSS) and colitis in the mouse CD $4+C D 45^{\mathrm{RB}}$ high $\mathrm{T}$ cell transfer model.

\section{Recognition of lactobacilli genomic DNA via TLR9}

Vertebrate innate immune system has evolved specific mechanisms to recognize bacterial DNA which differs from vertebrate DNA in respect of the frequency of methylated cytosin-guanodin dinucleotides (CpG motifs). In contrast to bacteria $\mathrm{CpG}$ motifs occur rarely in vertebrates and are mostly methylated [41]. TLR9 which is intracellular in immune cells but expressed on both the apical and basolateral recognizes bacterial CpG DNA and also synthetic unmethylated CpG oligonucleotide mimics (GpG-ODN) [42]. As the genome of Lactobacillus species differ in their $\mathrm{C}+\mathrm{G}$ composition the TLR9 stimulatory capacity of different species is also likely to be different.

In polarized epithelial cells basolateral TLR9 stimulation with CpG-ODN was shown to activate the NF- $\kappa \mathrm{B}$ pathway while apical stimulation prevented NF- $\kappa \mathrm{B}$ activation conferring tolerance to chronic TLR challenges [43]. In vitro treatment of human epithelial cell monolayers with various bacterial DNA has been reported to have differential effects on IL-8 secretion [44]. DNA from pathogenic species of Salmonella but not from Lactobacillius, Bifidobacterium and Streptococcus species present in the VSL3 probiotic mixture induced IL-8 secretion in the human colonic cell line HT29. Furthermore, pre-treatment of HT29 cells with DNA from VSL3 delayed NF- $\kappa \mathrm{B}$ activation, stabilized levels of $\mathrm{I} \kappa \mathrm{B}$ and attenuated IL- 8 secretion in response to Salmonella DNA or TNF $\alpha$ [44]. Similar effects were also recently reported for HT29 and T84 polarized cell monolayers using purified DNA from L. rhamnosus GG[45].

CpG DNA and synthetic CpG-ODN stimulate macrophages, dendritic cells and monocytes to produce Th1 cytokines and NK cells to produce IFN- $\gamma[46,47]$. Prolonged (6-9 h) pre-exposure of macrophages to $\mathrm{CpG}$ DNA can however attenuate production of the proinflammatory cytokine TNF $\alpha$ following subsequent challenge with LPS via induction of IL-10 expression [48]. In contrast brief pre-exposure $(1-3 \mathrm{~h})$ of the RAW 264.7 mouse macrophage cell line to CpG-ODN augments the proinflammatory cytokine response to LPS
[48]. Divergent effects of CpG-ODN have also been observed in experimental colitis where application of CpG-ODN in active disease exacerbated inflammation and prophylactic administration ameliorated colitis $[49,50]$. Recent studies in mice suggest that the prophylactic effects are due to the induction of regulatory properties in T cells [51].

VSL3 probiotic has been shown to reduce mucosal secretion of TNF $\alpha$ and IFN- $\gamma$ and improve histologic disease in IL-10 deficient mice (Jijon 2004). This protective effect appears to be mediated by TLR9-triggered type I IFN as the addition of neutralizing antibodies against type I IFN abolished the anti-inflammatory effects induced by TLR9 agonists, whereas the administration of recombinant IFN- $\beta$ mimicked the anti-inflammatory effects induced by TLR9 agonists [52]. The protective effect of VSL3 was also seen with non-viable or gamma-irradiated VSL3 probiotic, but not by heatkilled VSL3. Protection from colitis was seen with VSL3 in TLR2 and TL4 knockout mice but not TLR9 mice validating the role of TLR9 signaling in the probiotic mechanism [43].

In summary these studies suggest that unmethylated DNA fragments containing CpG motifs that are released from probiotics in vivo have potential to mediate antiinflammatory effects via TLR9 signaling at the epithelial surface. Additionally, bacterial DNA from commensal microbiota or probiotic bacteria may contribute to the steady-state homeostasis via the enhancement of regulatory mechanisms.

\section{Immune signalling via peptidoglycan}

Several studies report that preparations of macromolecular PGN (PGNpolymer) can activate NF- $\kappa$ B through human Toll-like receptors 2 (TLR2). However a recent study showed that purified peptidoglycan (PGN) isolated from $S$. aureus mutant lacking prolipoprotein diacylglyceryl transferase (Lgt) which couples the diacyl chains to lipoproteins in Gram-positive bacteria fails to stimulate TLR2 signalling [53]. This demonstrates that lipoproteins within the macromolecular structures of PGNpolymer, but not PGN itself, activate TLR2. Furthermore, an extensively purified monomeric PGN (PGNmonomer) failed to stimulate TLR2 signalling [53].

Peptidoglycan fragments are however recognized by the NOD1 and NOD2 members of the NLR family of PRR. There are more than 20 members of this receptor family in humans and they recognize a wide range of bacterial ligands and toxins as well as certain damageassociated molecular patterns (DAMPs) of the host cell $[19,54]$. NOD1 and NOD2 are the most well characterized NLRs and bind to the synthetic peptidoglycan mimics meso-diaminopimelic acid (DAP) and muramyl dipeptide (MDP), respectively [55,56] (Table 1$)$. Both 
receptors are typically expressed in immune cells but in the intestinal epithelium only NOD1 is expressed throughout the epithelium. NOD2 expression is predominantly expressed in Paneth cells in the small intestine [57]. NOD1 and NOD2 activating ligands such muramyl dipeptide and Tri-peptide mesoDAP are transported into epithelial cells by the PepT1 di/tripeptide transporter which is highly expressed in the small intestine. In the colon PepT1 is poorly expressed but is induced during chronic inflammation [58]. NOD1 ligands have also been shown to enter cells through endocytosis, in a $\mathrm{pH}$ dependent manner [59]. NOD1 and NOD2 can also detect peptidoglycan fragments produced in the phagosome or phagolysosome of antigen presenting cells although the nature of the transporters involved in translocation to the cytoplasm remains unknown [60].

Typically the unmodified glycan strands of bacterial peptidoglycan consist of repeating units of $\beta$-1,4-linked $\mathrm{N}$-acetylglucosamine and $\mathrm{N}$-acetylmuramic acid but may undergo different enzymatic modifications such as $\mathrm{O}$ acetylation [61]. In several lactobacilli the pentapeptide chains that are cross-linked between the D-alanine (Dala) and L-lysine (D-lys) also differ from the consensus for lactic acid bacteria (L-ala, D-glu, meso-diaminopimelic acid or L-lys, D-ala, D-ala) [62]. For example in $L$. casei and L. plantarum the terminal D-ala is replaced by D-lactate. In addition the D-asparagine that forms the bridge between the pentapeptides, can be amidated in $L$. acidophilus and some other Lactobacillus spp. [62,63]. Highly O-acetylated peptidoglycan might be resistant to the hydrolytic activity of human lysozyme, thereby affecting the release of NLR stimulating PGN fragments and innate immune responses of antigen presenting cells such as dendritic cells and macrophages.

NOD2 alone does not activate dendritic cells but it has been shown to act a potent co-stimulator of the innate immune response exclusively in the presence of TLR signals [53]. Addition of highly purified PGNmonomer isolated from $S$. aureus in combination with TLR agonists up-regulated production of IL-12p70 and IL-23 in DC [53]. This synergistic effect was lost in dendritic cells from NOD2 deficient mice showing that NOD2 is the bone-fide receptor for highly purified PGN monomer.

\section{Influence of exopolysaccharides on immune signalling} In addition to PGN and teichoic acids, exopolysaccharides (EPSs) are also commonly associated with the cell wall of lactobacilli. The EPSs may be attached to the cell wall or secreted into the milieu. The structural diversity is large due to the presence of different sugar monomers and also variation in the modes of linkage, substitution and branching [64]. Some S-layer proteins of lactobacilli appear to be glycosylated [65] and other surface proteins attached to the cell wall may also be glycosylated [66] EPSs and other cell wall polysaccharides could be recognized by one of several C-type lectin receptors (CLRs) that are involved in the recognition and capture of antigens by antigen presenting cells such as dendritic cells and macrophages.

The addition of heat-killed Lactobacillus casei Strain Shirota or its purified polysaccharide-peptidoglycan (PSPG) complex decreased production of IL-6 in LPS-treated RAW 264.7 cells [67]. A role of the cell wall polysaccharide-1 (PS-1) was subsequently confirmed by Yasuda and colleagues who compared the immune-suppressive properties of PS-1 mutants with the wild type strain [68]. It is not known whether any lactobacilli express immunomodulatory zwitterionic polysaccharides like the prototype PSA found in a non-toxin producing B. fragilis strain. This PSA is degraded in the phagolysosome by oxidative depolymerisation to yield fragments that can be presented by the MHC class II molecule to CD4+ T cells carrying $\alpha \beta-\mathrm{T}$ cell receptors [69]. B. fragilis PSA has been shown to influence the special and temporal development of $\mathrm{T}$ cell responses during colonization of germ-free mice and it can protect against colitis by a mechanism involving the induction of regulatory $\mathrm{T}$ cells and IL-10 production [69].

Some bacterial pathogens such as Mycobacterium tuberculosis and viral pathogens such as HIV-1 escape immune surveillance by targeting the C-type lectin DCSIGN (DC-specific intercellular adhesion molecule-grabbing non-integrin) on dendritic cells. Binding to this receptor is mediated by high mannose containing carbohydrate structures and affects maturation of DC and increases expression of IL-10. The result is reduced capacity of the DC to induce $\mathrm{T}$ cell-mediated responses against the pathogen. DC-SIGN binding activity has also been described for some strains of Lactobacillus spp. and is proposed to have an immunomodulatory effect $[70,71]$.

\section{In vitro assays of immunomodulation by lactobacilli}

In vitro co-culture assays with lactobacilli and different types of immune cells, such as human monocyte derived DCs, human PBMCs and mouse bone marrow derived DCs have often been used to assess the immunomodulatory potential of different species and strains (reviewed in [72]). IL-10 production is typically measured because it is an anti-inflammatory cytokine that suppresses IL-12 production and consequently IFN- $\gamma$ production, thus favouring a $\mathrm{T}$-helper 2 (Th2) or a regulatory $\mathrm{T}$ cell (Treg) response. In addition, IL-10 down-regulates antigen presentation and inhibits the activation of macrophages and thus the production of pro-inflammatory molecules and chemokines. IL-12 is also commonly measured as IL-12 production by DC is associated with 
the induction of T-helper 1 (Th1) responses. Furthermore IL-12 elicits IFN- $\gamma$ production by $T$ cells and by NK cells. There is a lack of evidence linking in vitro data to in vivo data for different strains but some studies indicate a correlation. Three studies have shown that the ability of different lactobacilli to induce a high ratio of IL-10/IL-12 or IL-10/TNF- $\alpha$ production in immune cells correlates with their capacity to provide significant protection in TNBS induced colitis in mice and rats [73-75]. Foligne et al., showed that the ranking of strains obtained on the basis of an in vitro IL-10/IL-12 cytokine induction ratio closely correlates the ranking of the in vivo ability of the strains to attenuate experimental colitis [73]. In contrast another study has shown that strains with similar cytokine ratios can have different outcomes in the mouse DSS model of colitis [76]. The reasons for their different immunomodulatory properties is not clear but may be due the levels of cytokines produced rather than the ratio and/or the survival and persistence of the strains in vivo.

Several studies have shown that the in vitro cytokine responses of human PBMC and DC to lactobacilli can be strikingly different depending on both the species and the strain [73,77-84]. As discussed further below different subsets of DC with distinct immunological phenotypes exist within the mucosal tissues so these in vitro models serve only as models to characterize the potential immunomodulatory properties of bacteria and or other factors (recently reviewed [72]). Despite these limitations there is evidence that the immune profile obtained in co-culture assays with bacteria and immune cells (especially for IL-10 and IL-12) can be predictive of their in vivo immunomodulatory activities [73,75,85].

Recently Meijerink et al., 2010 studied DC responses to $42 \mathrm{~L}$. plantarum strains and the amounts of IL-10 induced cytokines ranged from $28 \mathrm{pg} / \mathrm{mL}$ to $1095 \mathrm{pg} /$ $\mathrm{mL}$ (39 fold) for IL-10 and from 20-11996 pg/mL (600 fold) for IL-12 (Fig 3) [79]. From a comparison of IL-12 to IL-10 ratios it was clear that these cytokines can vary independently of each other resulting in strains with distinct pro-inflammatory and anti-inflammatory profiles. This remarkable diversity in the immunodulatory properties of different strains of the same species suggests that multiple factors can influence the phenotype in immune assays.

\section{Novel approaches to find immunomodulatory components of lactobacilli}

Comparative genomic analysis is one approach to identify genetic loci linked to certain phenotypes and has been applied to Lactobacillus spp. to identify a genes involved persistence in the intestine [86] and mannose binding [71]. Similarly, the natural diversity in the immune response to different strains of L. plantarum has been exploited to identify novel genes influencing the dendritic cell response to L. plantarum[79]. In this study the secreted cytokine amounts or cytokine ratios for the L. plantarum strains were correlated with the presence or absence of specific genes by regression using the Random Forest algorithm. The genotypic data for each strain was based on comparative hybridisation to a whole genome microarray of strain WCFS1. This limited the analysis to genes present in WCFS1 but nevertheless several interesting loci were identified. The absence of several plantaricin-related genes correlated with higher IL-10 production in co-culture with DC. Six of these genes ( $l p_{-} 0422, l p_{-} 0423, l p_{-} 0424 a, l p_{-} 0424$, $l p_{-} 0425$ and $l p_{-}$0429) were present within the locus (lp_0403 to lp_0431) required for plantaricin biosynthesis and secretion. Deletion mutants of the candidate genes were constructed in the WCFS1 strain in order to validate their anticipated effect on cytokine induction. All but one of the identified genes (a bile salt hydrolase) affected the immune response as predicted. All of the
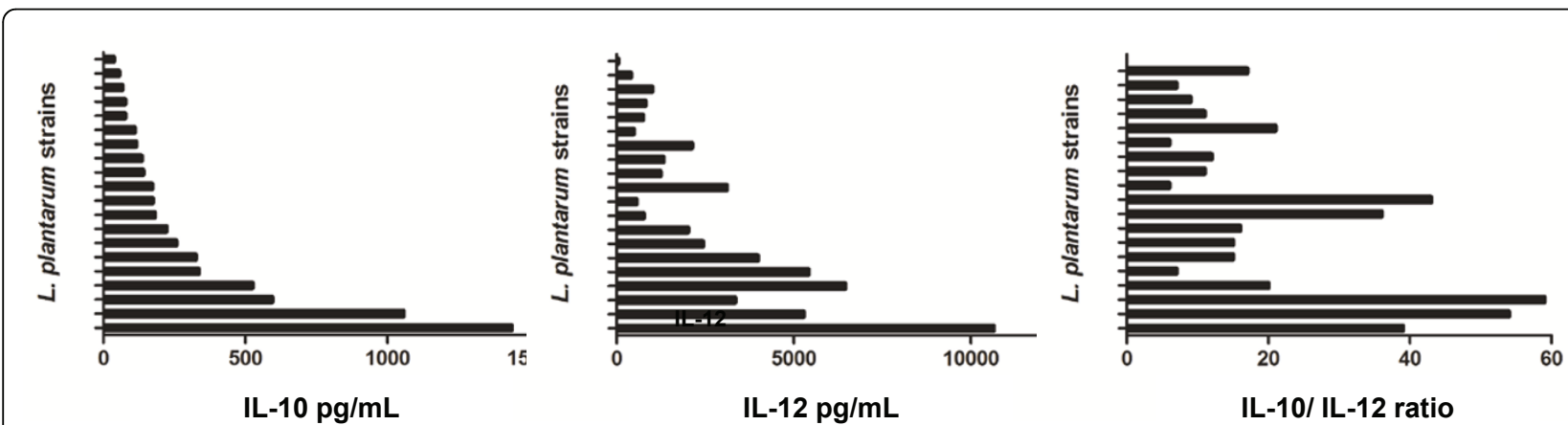

Figure 3 IL-10, IL-12p70 production and the IL-10/IL-12p70 ratio by monocyte-derived dendritic cells stimulated with 20 different $L$. plantarum strains. The graphs were produced using data from Meijerink et al., [69] based on one of the 5 representative donors. The different strains induce striking different amounts of these cytokines. Based on the IL-12 to IL-10 ratios it is clear that these cytokines can vary independently of each other resulting in strains with distinct pro-inflammatory and anti-inflammatory profiles. 
mutations introduced into the plataracin locus affected the immune response and were predicted to inhibit plantaracin production. Thus it is possible that the plantaracins directly affect the immune response of DC. Moreover, the expression of the L. plantarum plantaricin immunity protein PlnI is induced in the mouse intestine, suggesting that bacteriocins are produced in vivo[87].

Absence of a predicted transcriptional regulator gene $(l p-2991)$ was also correlated with higher production of IL-10 and TNF $\alpha$. A deletion mutant of $l p \_2991$, led to a significantly higher secretion of IL-10, IL-12p70 and TNF $\alpha$ compared to the wild-type control. This gene lies upstream of $g t c A 3$, a putative teichoic acid glycosylation protein. Upstream of $l p \_2991$ is a manganese transport gene $m n t H 2$ which is orientated in the opposite direction. Transcriptome analysis and qPCR data supported the hypothesis that lp_2991 is a repressor of gtcA3 transcription and points to this enzyme as being a prime candidate for the altered immune response. Interestingly GtcA3 is predicted to glycosylate TAs including LTA which is a known TLR2 agonist capable of modulating immune cell responses. As pointed out above an LTA mutant and mutants affecting D-ala substitution in LTA have already been found to have effects on the immune response [37,40].

An additional approach to identifying new immunomodulatory molecules involves the screening of metagenomic clone libraries in high throughput cell-based screening assays for NF-kB modulation. The development of such an assay was recently reported for the functional screening of human gut metagenome libraries [88]. Recently, tools have become available for the automated analysis of high-content spatio-temporal cellular events using multi-colour fluorescence microscopy in a highthroughput fashion. Advances in software capabilities in the extraction of quantitative measurements from the acquired images and the management and interpretation of terabytescale image data allows the combinatorial analysis of multiple parameters such as fluorescence intensity, distribution and co-localization as well as changes in cell shape, size or movement in real time [89]. Such an approach has potential to identify new microbial molecules involved in binding and signalling with host-cells for example by the use of strain collections or random and gene-targeted libraries in specific Lactobacillus strains. Selected small inhibitor RNA (siRNA) knockdown libraries could also be used in high-throughput screens to identify host genes leading to specific responses to bacterial strains or molecules.

\section{Immunomodulatory mechanisms in vivo}

Several in vivo studies involving probiotic lactobacilli point to an immunomodulatory effect on intestinal DCs.
Recently it was shown that administration of several strains of bacteria (including species of Lactobacillus, Bifidobacterium and Streptococcus) which had been selected in vitro to induce high IL-10 to IL-12 ratios were shown to expand the regulatory $\mathrm{T}$ cell population in the mesenteric lymph nodes [85]. Regulatory $\mathrm{T}$ cells (Tregs) are important in immunological tolerance due to the suppression of effector $\mathrm{T}$ cells at inflammatory sites and have therapeutic effects in models of inflammatory bowel disease, atopic dermatitis and rheumatoid arthritis. In the mucosa Tregs can be induced in the mucosal lymphoid tissues by a migratory population of tolerogenic $\mathrm{CD}_{103^{+}} \mathrm{DCs}$ distributed throughout the lamina propria (LP) of the whole intestine [90] (Fig 4). This population of DC is distinct from the epitheliumassociated $\mathrm{CX} 3 \mathrm{CR} 1^{+}$DCs and macrophages which

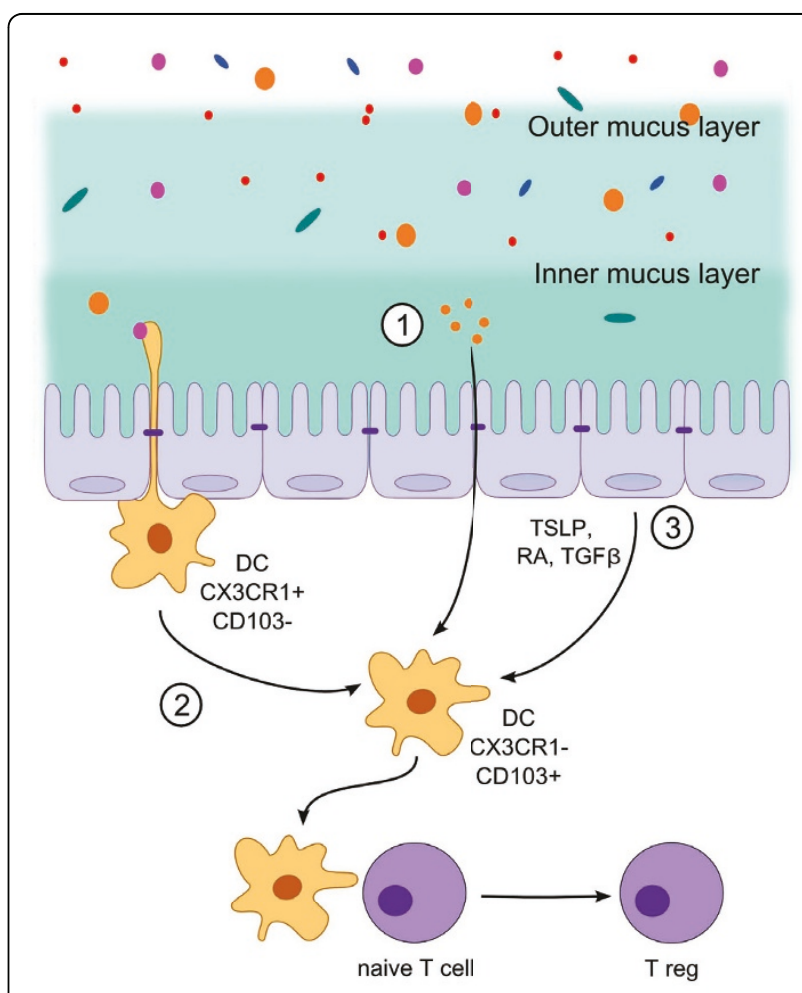

Figure 4 Potential immunomodulatory mechanisms of probiotic lactobacilli (1). It is not yet clear precisely how oral administration of certain strains of probiotic lactobacilli can expand the Treg population in the mesenteric lymph nodes but it may involve direct activation of lamina propria (LP) CD103+ DC by MAMPs leading to up-regulation of MHC II and the co-stimulatory molecules needed for signaling and antigen presentation to naïve $T$ cells in the lymphoid tissue. (2) Alternatively lactobacilli may be initially taken up by epithelial-associated $C \times 3 C R 1^{+}$DCs which could indirectly lead to maturation of the migratory CD103+ DC population. The oral administration of probiotic lactobacilli may also stimulate epithelial signaling and the production of cytokines such as TGF $\beta$ and TSLP as well as other factors which imprint a tolerogenic phenotype on resident CD103+ DC in the LP. 
participate in innate immune clearance and support inflammatory Th17 $\mathrm{T}$ cell responses [91,92]. The tolerogenic property of the $\mathrm{CD} 103^{+} \mathrm{CX} 3 \mathrm{CR} 1^{-} \mathrm{DC}$ subset is determined by their local tissue environment and in particular by epithelial derived transforming-growth factor beta (TGF- $\beta$ ), retinoic acid (RA) and in humans, also thymic stromal lymphopoietin (TSLP) $[93,94]$. Interestingly, these factors are induced in IECs after apical interaction with bacteria in vitro. This suggests that that luminal contact with bacteria or bacterial factors can potentially modulate DC function in the LP. The CD103 ${ }^{+} \mathrm{DC}$ also express the enzyme indoleamine 2,3 dioxygenase (IDO) which is required for their tolerogenic function [95]. The immunosuppressive effects of IDO are linked to its catabolism of tryptophan and and/or production of immunomodulatory metabolites [95]. Most of our understanding of this tolerogenic mechanism is based on studies in the mouse but the migratory $\mathrm{CD}_{103^{+}} \mathrm{DC}$ subset is also found in the LP and mesenteric lymph nodes (MLNs) of humans suggesting the mechanisms are conserved.

It is not yet clear precisely how oral administration of lactobacilli can expand the Treg population in the mesenteric lymph nodes [85] but it may involve activation of LP DC leading to up-regulation of MHC II and the co-stimulatory molecules needed for signalling and antigen presentation to naïve $\mathrm{T}$ cells. This effect may be indirect e.g. by uptake of lactobacilli by the non-migratory DC subset associated with the epithelium (Fig 4). Another possibility is that oral administration of probiotic lactobacilli stimulates epithelial signalling and the production of cytokines such as TGF $\beta$ and TSLP as well as other factors which serve to imprint a tolerogenic phenotype on resident $\mathrm{CD}_{103}{ }^{+} \mathrm{DC}$ in the LP (Fig 4).

A major gap in our knowledge about the mechanisms of immunomodulation by probiotics (including lactobacilli) concerns their fate in vivo. Studies on the thickness and physical state of the mucus layer throughout the intestinal tract has shown that it is thickest in the colon $(\sim 830 \mu \mathrm{m})$ and thinnest in the jejunum $(\sim 123 \mu \mathrm{m})$ [96]. If the mucus is removed by suction, a continuous, firmly adherent mucus layer remains attached to the epithelial surface in the colon $(\sim 116 \mu \mathrm{m})$ but in the small intestine this is much thinner $(\sim 20 \mu \mathrm{m})$ or absent [96]. The firm adherent layer of mucus in the colon is relatively devoid of bacteria [97] showing that the mucus layer is a significant physical barrier to contact of microbes with the epithelium. In the small intestine microbial contact with the epithelium may be more frequent due to the thinner layer of adherent mucus. Additionally the follicular epithelium covering the mucosal associated lymphoid tissue of the Peyer's Patches (PP) in the small intestine is considered to be more accessible to antigens and bacteria present in the luminal compartment.
Evidence that the mucosal tissue responds to orally consumed lactobacilli comes from recent studies on the mucosal transcriptome responses to orally consumed $L$. plantarum in humans $[98,99]$. In the study of Baarlen et al., [99] 3 preparations of $L$. plantarum were tested in a double-blind placebo-controlled cross-over design: (i) the logarithmic-phase of growth, (ii) the stationaryphase of growth, and (iii) heat-killed "stationary" bacteria. The microarray expression profiles of duodenal biopsies taken $6 \mathrm{~h}$ after consumption displayed striking differences including genes encoding NF-kB subunits and inhibitors of NF-kB signalling pathways. In a follow study transcriptomes of proximal small intestine biopsies from healthy volunteers were obtained after consumption of three widely used probiotic strains of different Lactobacillus species (about $1 \times 10^{10}$ bacteria) and a placebo control according to a randomized double-blind cross-over study design [100]. At 6 h each Lactobacillus strain induced markedly different expression profiles in the human mucosa, supporting other evidence from in vitro and in vivo studies that the beneficial properties of probiotics are strain dependent. Notably, there was a large person-to-person variation in the transcriptome response and a high co-efficient of variation for some of the chemokine and cytokine effectors which could help to explain the outcomes of probiotics reported in human studies.

\section{Influence of lactobacilli on antibody responses and immunity}

Lactobacilli have been shown to increase the immunogenicity of orally administered vaccines such as rotavirus [101], polio [102], cholera [103] and influenza virus vaccine [104]. In the study on cholera vaccination several probiotic strains were tested for their effect on antibody responses to the commercial oral cholera vaccine (Dukoral, SBL Vaccin AB, Stockholm, Sweden). The probiotic strains were given daily over a 3 week including the period in which the oral vaccine was administered. Immunoglobulin serum concentrations tended to increase in most probiotic treated groups and between day 0 and day 21 significant increases in IgG were observed for Bifidobacterium lactis B1-04 and Lactobacillus acidophilus La-14 compared to controls $(\mathrm{P}=0.01)$. However, no effect was observed on the final end point serum antibody titres to the vaccine or the specific IgA concentration in saliva [103]. Consumption of LGG or L. acidophilus CRL431 for five weeks doubled neutralization titres to an oral polio vaccine given in the fifth week [102]. In the group consuming probiotics marked increases in polio-virus specific IgA was also observed after vaccination. The adjuvant effect of LGG was also evaluated in conjunction with D $x$ RRV rhesus-human reassortant live oral rotavirus vaccine in 2-5-month-old 
infants. Infants who received LGG showed an increased response with regard to rotavirus-specific IgM secreting cells on day 8 after vaccination. In infants receiving LGG rotavirus IgM seroconversion was not significantly different to placebo. However, rotavirus IgA seroconversion was detected in 26/28 (93\%) of cases in the LGG group versus 20/27 (74\%) infants given the placebo ( $\mathrm{p}=$ 0.05 ) suggesting that LGG has an immunostimulating effect on oral rotavirus vaccination. Oral consumption of non-viable Lactobacillus pentosus strain b240 enhanced secretory IgA concentrations in the saliva of healthy volunteers [105] and more recently this strain was shown to increase survival time of mice infected with a lethal dose of influenza virus [104]. The adjuvant and immunomodulatory effects of lactobacilli on immunity are also evident from many studies utilising lactic acid bacteria as vaccine delivery vehicles for mucosal immunization [23,106].

There is also evidence that orally consumed probiotics can stimulate immune responses to respiratory pathogens [107]. Furthermore a recent study on orally consumed LGG as an immune adjuvant for live attenuated influenza vaccination in healthy adults which showed significantly improved protective serum responses to one of the three viruses present in the vaccine [108].

\section{Innate signalling and barrier function}

Epithelial cells play a key role in directing the responses in the gut and maintaining homeostasis via the sensing of microbes or MAMPs (reviewed in [23]). Commensal bacteria are not ignored but dynamically controlled via many complex overlapping and intertwined mechanisms involving IECs and signals from the microbiota. Inflammation is avoided through the differential signalling and expression of receptors on the apical and basal membranes of the epithelium and via the regulation of pattern-recognition receptor expression and activity $[17,18,43]$. Moreover TLR signalling has been shown to have a protective role in the intestine $[109,110]$. Several lactobacilli have been reported to enhance barrier function and/or protect against barrier disruption by pathogens in vitro (reviewed recently [111,112]). Different strains of Lactobacillus plantarum have been reported to prevent the reduction in trans-epithelial resistance across epithelial monolayers caused by pathogenic E.coli when co-cultured with the pathogen. This could be due to inhibition of the pathogen or enhancement of the barrier function by modulating $\mathrm{TJ}$ composition [113-115]. Lactobacilli have also been reported to reverse the barrier dysfunction caused by proinflammatory cytokines in vitro[116].

In animal models $L$. plantarum strains have been shown to reduce the hyper-permeability associated with experimental enterocolitis [117] and biliary obstruction
[118]. Recently a study was performed in human volunteers which showed that perfusion of L. plantarum into the duodenum increased the localization (immunofluorescent staining) of occludin and ZO-1 in the epithelial TJs of tissue biopsies [119]. TJ modification was mediated by TLR2 ligands and conferred protection against disruption of the TJs by phorbol ester in vitro. These results are in agreement with recent studies in mice showing protection from colitis by administration of TLR2 ligands [109]. The precise signalling mechanisms leading to TJ modulation by lactobacilli are not clear but specific PKC isoforms have been implicated from in vitro studies with TLR2 agonists [109]. This does not exclude the involvement of other mechanisms and receptors in $\mathrm{TJ}$ modification by lactobacilli such as EGF, the ERK1/2 members of the MAPK family [120-122].

\section{Conclusions}

Lactobacilli can elicit innate and adaptive immune responses in the host is via binding to pattern recognition receptors (PRR) expressed on immune cells and many other tissues including the intestinal epithelium. The di-acylated membrane anchors of lipoproteins and lipoteichoic acids bind to TLR2 and TLR6 promoting dimerization and MyD88-mediated activation of the canonical pathway of NF-kB. The capacity of different species to stimulate TLR2 signalling varies considerably, even at the strain level for those species which have been extensively tested (unpublished Taverne, Meijerink and Wells). This may reflect differences in the expression level of certain lipoproteins, their release into the medium, the amount of LTA and its structure/ modification and the effect of shielding factors such as exopolysacchrides. Strain-dependent differences in MAMPs such as LTA, the peptidoglycan structure and nonmethylated CpG motifs could explain why the in vitro cytokine responses of human PBMC and DC to lactobacilli can be strikingly different depending on both the species and the strain. Furthermore, sugars present in the cell wall and the post-translational modification of proteins with carbohydrates can also modulate the immune response by binding to $\mathrm{C}$-type lectin binding receptors. It seems likely that more new strain-specific genes and factors that modulate innate recognition by the host will be discovered using gene-trait matching, functional metagenomic screens, and high throughput automated microscopy $[79,88]$.

In vivo lactobacilli have been successfully used to modulate inflammatory diseases, enhance barrier functions and stimulate immunity. Evidence linking these beneficial properties to in vitro immune data is sparse due to the lack of comparative studies with different strains of probiotics in vitro and in vivo. Nevertheless, 
the immune profile obtained in co-culture assays with bacteria and immune cells (especially for IL-10 and IL12) has been shown to be predictive of their anti-inflammatory properties $[73,85]$. Studies in mice indicate that certain strains of probiotics can be used prevent or treat inflammatory diseases via a mechanism which increases mucosal Treg cells [85]. This most likely involves the mucosal CD103+ DC that traffic between the lamina propria and draining lymphoid tissue in humans and mice. The tolerogenic phenotype of these DC is imprinted by secreted factors produced by epithelial cells and other cells and thus may be subject to regulation by epithelial interactions with the luminal microbiota. Increasing evidence also suggests that induction of epithelial signalling by non-pathogenic commensals in the lumen can modulate barrier functions and regulate inflammatory signalling [Karczewski 2010; Neish 2000; Kelly 2004\}. Other probiotic mechanisms are likely to include modulation of the $\mathrm{T}$ effector subsets and the CX3CR1+ LP cells that can sample bacteria through the epithelium [93]. A major challenge for the future will be to gain a better understanding of how probiotics can modulate DC function in the LP and DC in vivo especially in humans where sampling of immune cells at mucosal sites is difficult to the invasive nature of the technique.

\section{Acknowledgements}

The author is very grateful to Oriana Rossi for providing Figures 2 and 4 and Marjolein Meijerink for Figure 3. JW is a member of the Marie Curie Initial Training Networks "Cross-talk" (PITN-GA-2008-215553) and "STARS" (Grant agreement no.: 238490) and gratefully acknowledges financial support to his laboratory.

This article has been published as part of Microbial Cell Factories Volume 10 Supplement 1, 2011: Proceedings of the 10th Symposium on Lactic Acid Bacterium. The full contents of the supplement are available online at http:// www.microbialcellfactories.com/supplements/10/S1.

\section{Competing interests}

The author has no competing interests.

Published: 30 August 2011

\section{References}

1. Claesson MJ, van Sinderen D, O'Toole PW: The genus Lactobacillus-a genomic basis for understanding its diversity. FEMS Microbiol Lett 2007, 269(1):22-28.

2. Lebeer S, Vanderleyden J, De Keersmaecker SC: Genes and molecules of lactobacilli supporting probiotic action. Microbiol Mol Biol Rev 2008, 72(4):728-764, Table of Contents.

3. Mackie Rl, Sghir A, Gaskins HR: Developmental microbial ecology of the neonatal gastrointestinal tract. Am J Clin Nutr 1999, 69(5):1035S-1045S.

4. Falagas ME, Betsi Gl, Athanasiou S: Probiotics for the treatment of women with bacterial vaginosis. Clin Microbiol Infect 2007, 13(7):657-664.

5. Ligaarden SC, Axelsson L, Naterstad K, Lydersen S, Farup PG: A candidate probiotic with unfavourable effects in subjects with irritable bowel syndrome: a randomised controlled trial. BMC Gastroenterol 2010, 10:16.

6. Brouwer ML, Wolt-Plompen SA, Dubois AE, van der Heide S, Jansen DF, Hoijer MA, Kauffman HF, Duiverman EJ: No effects of probiotics on atopic dermatitis in infancy: a randomized placebo-controlled trial. Clin Exp Allergy 2006, 36(7):899-906.
7. Folster-Holst R, Muller F, Schnopp N, Abeck D, Kreiselmaier I, Lenz T, von Ruden U, Schrezenmeir J, Christophers E, Weichenthal M: Prospective, randomized controlled trial on Lactobacillus rhamnosus in infants with moderate to severe atopic dermatitis. Br J Dermatol 2006, 155(6):1256-1261.

8. Gruber C, Wendt M, Sulser C, Lau S, Kulig M, Wahn U, Werfel T, Niggemann B: Randomized, placebo-controlled trial of Lactobacillus rhamnosus GG as treatment of atopic dermatitis in infancy. Allergy 2007, 62(11):1270-1276.

9. Majamaa $H$, Isolauri E: Probiotics: a novel approach in the management of food allergy. J Allergy Clin Immunol 1997, 99(2):179-185.

10. Sazawal S, Hiremath G, Dhingra U, Malik P, Deb S, Black RE: Efficacy of probiotics in prevention of acute diarrhoea: a meta-analysis of masked, randomised, placebo-controlled trials. Lancet Infect Dis 2006, 6(6):374-382.

11. Isolauri E, Arvola T, Sutas $Y$, Moilanen E, Salminen S: Probiotics in the management of atopic eczema. Clin Exp Allergy 2000, 30(11):1604-1610.

12. Viljanen M, Savilahti E, Haahtela T, Juntunen-Backman K, Korpela R, Poussa T, Tuure T, Kuitunen M: Probiotics in the treatment of atopic eczema/dermatitis syndrome in infants: a double-blind placebocontrolled trial. Allergy 2005, 60(4):494-500.

13. Kalliomaki M, Salminen S, Arvilommi H, Kero P, Koskinen P, Isolauri E: Probiotics in primary prevention of atopic disease: a randomised placebo-controlled trial. Lancet 2001, 357(9262):1076-1079.

14. Kalliomaki M, Salminen S, Poussa T, Arvilommi H, Isolauri E: Probiotics and prevention of atopic disease: 4-year follow-up of a randomised placebocontrolled trial. Lancet 2003, 361(9372):1869-1871.

15. Kalliomaki M, Antoine JM, Herz U, Rijkers GT, Wells JM, Mercenier A: Guidance for substantiating the evidence for beneficial effects of probiotics: prevention and management of allergic diseases by probiotics. J Nutr 2010, 140(3):713S-721S.

16. Vliagoftis $H$, Kouranos VD, Betsi Gl, Falagas ME: Probiotics for the treatment of allergic rhinitis and asthma: systematic review of randomized controlled trials. Ann Allergy Asthma Immunol 2008, 101(6):570-579.

17. Wells JM, Loonen LM, Karczewski JM: The role of innate signaling in the homeostasis of tolerance and immunity in the intestine. Int J Med Microbiol 2010, 300(1):41-48.

18. Abreu MT: Toll-like receptor signalling in the intestinal epithelium: how bacterial recognition shapes intestinal function. Nat Rev Immunol 2010, 10(2):131-144.

19. Kawai T, Akira S: The role of pattern-recognition receptors in innate immunity: update on Toll-like receptors. Nat Immunol 2010, 11(5):373-384.

20. Janssens $S$, Beyaert R: A universal role for MyD88 in TLR/IL-1R-mediated signaling. Trends Biochem Sci 2002, 27(9):474-482.

21. Rescigno M: Intestinal dendritic cells. Adv Immunol 2010, 107:109-138.

22. Kapsenberg ML: Dendritic-cell control of pathogen-driven T-cell polarization. Nat Rev Immunol 2003, 3(12):984-993.

23. Wells JM, Rossi O, Meijerink M, van Baarlen P: Epithelial crosstalk at the microbiota-mucosal interface. Proc Natl Acad Sci U S A 2011, 108(Suppl 1):4607-4614.

24. Furrie E, Macfarlane S, Thomson G, Macfarlane GT: Toll-like receptors-2, -3 and -4 expression patterns on human colon and their regulation by mucosal-associated bacteria. Immunology 2005, 115(4):565-574.

25. Abreu MT, Arnold ET, Thomas LS, Gonsky R, Zhou Y, Hu B, Arditi M: TLR4 and MD-2 expression is regulated by immune-mediated signals in human intestinal epithelial cells. J Biol Chem 2002, 277(23):20431-20437.

26. Cario E, Podolsky DK: Differential alteration in intestinal epithelial cell expression of toll-like receptor 3 (TLR3) and TLR4 in inflammatory bowel disease. Infect Immun 2000, 68(12):7010-7017.

27. Chabot S, Wagner JS, Farrant S, Neutra MR: TLRs regulate the gatekeeping functions of the intestinal follicle-associated epithelium. J Immunol 2006, 176(7):4275-4283.

28. Brightbill HD, Libraty DH, Krutzik SR, Yang RB, Belisle JT, Bleharski JR, Maitland M, Norgard MV, Plevy SE, Smale ST, et al: Host defense mechanisms triggered by microbial lipoproteins through toll-like receptors. Science 1999, 285(5428):732-736.

29. Aliprantis AO, Yang RB, Mark MR, Suggett S, Devaux B, Radolf JD, Klimpel GR, Godowski P, Zychlinsky A: Cell activation and apoptosis by bacterial lipoproteins through toll-like receptor-2. Science 1999, 285(5428):736-739. 
30. Hutchings MI, Palmer T, Harrington DJ, Sutcliffe IC: Lipoprotein biogenesis in Gram-positive bacteria: knowing when to hold 'em, knowing when to fold 'em. Trends Microbiol 2009, 17(1):13-21.

31. Takeuchi O, Sato S, Horiuchi T, Hoshino K, Takeda K, Dong Z, Modlin RL, Akira S: Cutting edge: role of Toll-like receptor 1 in mediating immune response to microbial lipoproteins. J Immunol 2002, 169(1):10-14.

32. Jin MS, Kim SE, Heo JY, Lee ME, Kim HM, Paik SG, Lee H, Lee JO: Crystal structure of the TLR1-TLR2 heterodimer induced by binding of a triacylated lipopeptide. Cell 2007, 130(6):1071-1082.

33. Kang JY, Nan X, Jin MS, Youn SJ, Ryu YH, Mah S, Han SH, Lee H, Paik SG, Lee JO: Recognition of lipopeptide patterns by Toll-like receptor 2-Tolllike receptor 6 heterodimer. Immunity 2009, 31(6):873-884.

34. Hermann C, Spreitzer I, Schroder NW, Morath S, Lehner MD, Fischer W, Schutt C, Schumann RR, Hartung T: Cytokine induction by purified lipoteichoic acids from various bacterial species-role of LBP, SCD14, CD14 and failure to induce IL-12 and subsequent IFN-gamma release. Eur J Immunol 2002, 32(2):541-551.

35. Hoebe K, Georgel P, Rutschmann S, Du X, Mudd S, Crozat K, Sovath S, Shamel L, Hartung T, Zahringer U, et al: CD36 is a sensor of diacylglycerides. Nature 2005, 433(7025):523-527.

36. Dunne DW, Resnick D, Greenberg J, Krieger M, Joiner KA: The type I macrophage scavenger receptor binds to gram-positive bacteria and recognizes lipoteichoic acid. Proc Natl Acad Sci U S A 1994, 91(5):1863-1867.

37. Grangette C, Nutten S, Palumbo E, Morath S, Hermann C, Dewulf J, Pot B, Hartung T, Hols P, Mercenier A: Enhanced antiinflammatory capacity of a Lactobacillus plantarum mutant synthesizing modified teichoic acids. Proc Natl Acad Sci U S A 2005, 102(29):10321-10326.

38. Deininger S, Figueroa-Perez I, Sigel S, Stadelmaier A, Schmidt RR, Hartung T, von Aulock S: Use of synthetic derivatives to determine the minimal active structure of cytokine-inducing lipoteichoic acid. Clin Vaccine Immunol 2007, 14(12):1629-1633.

39. Perea Velez M, Verhoeven TL, Draing C, Von Aulock S, Pfitzenmaier M, Geyer A, Lambrichts I, Grangette C, Pot B, Vanderleyden J, et al: Functional analysis of D-alanylation of lipoteichoic acid in the probiotic strain Lactobacillus rhamnosus GG. Appl Environ Microbiol 2007, 73(11):3595-3604.

40. Mohamadzadeh M, Pfeiler EA, Brown JB, Zadeh M, Gramarossa M, Managlia E, Bere P, Sarraj B, Khan MW, Pakanati KC, et al: Regulation of induced colonic inflammation by Lactobacillus acidophilus deficient in lipoteichoic acid. Proc Natl Acad Sci U S A 2011, 108(Suppl 1):4623-4630.

41. Stacey KJ, Young GR, Clark F, Sester DP, Roberts TL, Naik S, Sweet MJ, Hume DA: The molecular basis for the lack of immunostimulatory activity of vertebrate DNA. J Immunol 2003, 170(7):3614-3620.

42. Hemmi H, Takeuchi O, Kawai T, Kaisho T, Sato S, Sanjo H, Matsumoto M, Hoshino K, Wagner $\mathrm{H}$, Takeda $\mathrm{K}$, et al: A Toll-like receptor recognizes bacterial DNA. Nature 2000, 408(6813):740-745.

43. Lee J, Mo JH, Katakura K, Alkalay I, Rucker AN, Liu YT, Lee HK, Shen C, Cojocaru G, Shenouda S, et al: Maintenance of colonic homeostasis by distinctive apical TLR9 signalling in intestinal epithelial cells. Nat Cell Biol 2006, 8(12):1327-1336.

44. Jijon H, Backer J, Diaz H, Yeung H, Thiel D, McKaigney C, De Simone C, Madsen K: DNA from probiotic bacteria modulates murine and human epithelial and immune function. Gastroenterology 2004, 126(5):1358-1373.

45. Ghadimi D, Vrese M, Heller KJ, Schrezenmeir J: Effect of natural commensal-origin DNA on toll-like receptor 9 (TLR9) signaling cascade, chemokine IL-8 expression, and barrier integritiy of polarized intestinal epithelial cells. Inflamm Bowel Dis 2010, 16(3):410-427.

46. Hornung V, Rothenfusser S, Britsch S, Krug A, Jahrsdorfer B, Giese T, Endres S, Hartmann G: Quantitative expression of toll-like receptor 1-10 mRNA in cellular subsets of human peripheral blood mononuclear cells and sensitivity to CpG oligodeoxynucleotides. J Immunol 2002, 168(9):4531-4537.

47. Cowdery JS, Chace JH, Yi AK, Krieg AM: Bacterial DNA induces NK cells to produce IFN-gamma in vivo and increases the toxicity of lipopolysaccharides. J Immunol 1996, 156(12):4570-4575.

48. Crabtree TD, Jin L, Raymond DP, Pelletier SJ, Houlgrave CW, Gleason TG, Pruett TL, Sawyer RG: Preexposure of murine macrophages to $\mathrm{CpG}$ oligonucleotide results in a biphasic tumor necrosis factor alpha response to subsequent lipopolysaccharide challenge. Infect Immun 2001, 69(4):2123-2129.
49. Obermeier F, Dunger N, Strauch UG, Grunwald N, Herfarth H, Scholmerich J, Falk W: Contrasting activity of cytosin-guanosin dinucleotide oligonucleotides in mice with experimental colitis. Clin Exp Immunol 2003, 134(2):217-224

50. Rachmilewitz D, Karmeli F, Takabayashi K, Hayashi T, Leider-Trejo L, Lee J, Leoni LM, Raz E: Immunostimulatory DNA ameliorates experimental and spontaneous murine colitis. Gastroenterology 2002, 122(5):1428-1441.

51. Obermeier F, Strauch UG, Dunger N, Grunwald N, Rath HC, Herfarth $H$, Scholmerich J, Falk W: In vivo CpG DNA/toll-like receptor 9 interaction induces regulatory properties in $\mathrm{CD} 4+\mathrm{CD} 62 \mathrm{~L}+\mathrm{T}$ cells which prevent intestinal inflammation in the SCID transfer model of colitis. Gut 2005, 54(10):1428-1436.

52. Katakura K, Lee J, Rachmilewitz D, Li G, Eckmann L, Raz E: Toll-like receptor 9-induced type I IFN protects mice from experimental colitis. J Clin Invest 2005, 115(3):695-702.

53. Volz T, Nega M, Buschmann J, Kaesler S, Guenova E, Peschel A, Rocken M, Gotz F, Biedermann T: Natural Staphylococcus aureus-derived peptidoglycan fragments activate NOD2 and act as potent costimulators of the innate immune system exclusively in the presence of TLR signals. Faseb J 2010, 24(10):4089-4102

54. Ting JP, Willingham SB, Bergstralh DT: NLRs at the intersection of cell death and immunity. Nat Rev Immunol 2008, 8(5):372-379.

55. Girardin SE, Boneca IG, Carneiro LA, Antignac A, Jehanno M, Viala J, Tedin K, Taha MK, Labigne A, Zahringer U, et al: Nod1 detects a unique muropeptide from gram-negative bacterial peptidoglycan. Science 2003, 300(5625):1584-1587.

56. Girardin SE, Boneca IG, Viala J, Chamaillard M, Labigne A, Thomas G, Philpott DJ, Sansonetti PJ: Nod2 is a general sensor of peptidoglycan through muramyl dipeptide (MDP) detection. J Biol Chem 2003, 278(11):8869-8872

57. Lala S, Ogura Y, Osborne C, Hor SY, Bromfield A, Davies S, Ogunbiyi O, Nunez G, Keshav S: Crohn's disease and the NOD2 gene: a role for paneth cells. Gastroenterology 2003, 125(1):47-57.

58. Dalmasso G, Nguyen HT, Charrier-Hisamuddin L, Yan Y, Laroui H, Demoulin B, Sitaraman SV, Merlin D: PepT1 mediates transport of the proinflammatory bacterial tripeptide L-Ala-\{gamma\}-D-Glu-meso-DAP in intestinal epithelial cells. Am J Physiol Gastrointest Liver Physiol 2010, 299(3):G687-696.

59. Lee J, Tattoli I, Wojtal KA, Vavricka SR, Philpott DJ, Girardin SE: pHdependent internalization of muramyl peptides from early endosomes enables Nod1 and Nod2 signaling. J Biol Chem 2009, 284(35):23818-23829.

60. Philpott DJ, Girardin SE: Nod-like receptors: sentinels at host membranes. Curr Opin Immunol 2010, 22(4):428-434.

61. Billot-Klein D, Legrand R, Schoot B, van Heijenoort J, Gutmann L: Peptidoglycan structure of Lactobacillus casei, a species highly resistant to glycopeptide antibiotics. J Bacteriol 1997, 179(19):6208-6212.

62. Delcour J, Ferain T, Deghorain M, Palumbo E, Hols P: The biosynthesis and functionality of the cell-wall of lactic acid bacteria. Antonie Van Leeuwenhoek 1999, 76(1-4):159-184.

63. Coyette J, Ghuysen JM: Structure of the walls of Lactobacillus acidophilus strain 63 AM Gasser. Biochemistry 1970, 9(15):2935-2943.

64. De Vuyst L, Degeest B: Heteropolysaccharides from lactic acid bacteria. FEMS Microbiol Rev 1999, 23(2):153-177.

65. Mobili P, Serradell Mde L, Trejo SA, Aviles Puigvert FX, Abraham AG, De Antoni GL: Heterogeneity of S-layer proteins from aggregating and nonaggregating Lactobacillus kefir strains. Antonie Van Leeuwenhoek 2009, 95(4):363-372

66. Francius G, Lebeer S, Alsteens D, Wildling L, Gruber HJ, Hols P, De Keersmaecker S, Vanderleyden J, Dufrene YF: Detection, localization, and conformational analysis of single polysaccharide molecules on live bacteria. ACS Nano 2008, 2(9):1921-1929.

67. Matsumoto S, Hara T, Hori T, Mitsuyama K, Nagaoka M, Tomiyasu N, Suzuki A, Sata M: Probiotic Lactobacillus-induced improvement in murine chronic inflammatory bowel disease is associated with the downregulation of pro-inflammatory cytokines in lamina propria mononuclear cells. Clin Exp Immunol 2005, 140(3):417-426.

68. Yasuda E, Serata M, Sako T: Suppressive effect on activation of macrophages by Lactobacillus casei strain Shirota genes determining the synthesis of cell wall-associated polysaccharides. Appl Environ Microbiol 2008, 74(15):4746-4755. 
69. Mazmanian SK, Liu CH, Tzianabos AO, Kasper DL: An immunomodulatory molecule of symbiotic bacteria directs maturation of the host immune system. Cell 2005, 122(1):107-118.

70. Konstantinov SR, Smidt H, de Vos WM, Bruijns SC, Singh SK, Valence F, Molle D, Lortal S, Altermann E, Klaenhammer TR, et al: $\mathrm{S}$ layer protein A of Lactobacillus acidophilus NCFM regulates immature dendritic cell and T cell functions. Proc Natl Acad Sci U S A 2008, 105(49):19474-19479.

71. Pretzer G, Snel J, Molenaar D, Wiersma A, Bron PA, Lambert J, de Vos WM, van der Meer R, Smits MA, Kleerebezem M: Biodiversity-based identification and functional characterization of the mannose-specific adhesin of Lactobacillus plantarum. J Bacterio/ 2005, 187(17):6128-6136.

72. Meijerink M, Wells JM: Probiotic modulation of dendritic cells and T cell responses in the intestine. Beneficial Microbes 2010, 1(4):317-216.

73. Foligne B, Nutten $S$, Grangette $C$, Dennin V, Goudercourt D, Poiret S, Dewulf J, Brassart D, Mercenier A, Pot B: Correlation between in vitro and in vivo immunomodulatory properties of lactic acid bacteria. World J Gastroenterol 2007, 13(2):236-243.

74. Zoumpopoulou G, Tsakalidou E, Dewulf J, Pot B, Grangette C: Differential crosstalk between epithelial cells, dendritic cells and bacteria in a coculture model. Int J Food Microbiol 2009, 131(1):40-51.

75. Peran L, Camuesco D, Comalada M, Nieto A, Concha A, Diaz-Ropero MP, Olivares M, Xaus J, Zarzuelo A, Galvez J: Preventative effects of a probiotic Lactobacillus salivarius ssp. salivarius, in the TNBS model of rat colitis. World J Gastroenterol 2005, 11(33):5185-5192.

76. Mileti E, Matteoli G, Iliev ID, Rescigno M: Comparison of the immunomodulatory properties of three probiotic strains of Lactobacilli using complex culture systems: prediction for in vivo efficacy. PLoS One 2009, 4(9):e7056.

77. Christensen HR, Frokiaer H, Pestka JJ: Lactobacilli differentially modulate expression of cytokines and maturation surface markers in murine dendritic cells. J Immunol 2002, 168(1):171-178.

78. van Hemert S, Meijerink M, Molenaar D, Bron PA, de Vos P, Kleerebezem M, Wells JM, Marco ML: Identification of Lactobacillus plantarum genes modulating the cytokine response of human peripheral blood mononuclear cells. BMC Microbiol 2010, 10:293.

79. Meijerink M, van Hemert S, Taverne N, Wels M, de Vos P, Bron PA Savelkoul HF, van Bilsen J, Kleerebezem M, Wells JM: Identification of genetic loci in Lactobacillus plantarum that modulate the immune response of dendritic cells using comparative genome hybridization. PLoS One 2010, 5(5):e10632.

80. Vissers YM, Snel J, Zuurendonk PF, Smit BA, Wichers HJ, Savelkoul HF: Differential effects of Lactobacillus acidophilus and Lactobacillus plantarum strains on cytokine induction in human peripheral blood mononuclear cells. FEMS Immunol Med Microbiol 2010, 59(1):60-70.

81. Miettinen M, Matikainen S, Vuopio-Varkila J, Pirhonen J, Varkila K, Kurimoto M, Julkunen I: Lactobacilli and streptococci induce interleukin12 (IL-12), IL-18, and gamma interferon production in human peripheral blood mononuclear cells. Infect Immun 1998, 66(12):6058-6062.

82. Miettinen $M$, Vuopio-Varkila J, Varkila K: Production of human tumor necrosis factor alpha, interleukin-6, and interleukin-10 is induced by lactic acid bacteria. Infect Immun 1996, 64(12):5403-5405

83. Niers LE, Hoekstra MO, Timmerman HM, van Uden NO, de Graaf PM, Smits HH, Kimpen JL, Rijkers GT: Selection of probiotic bacteria for prevention of allergic diseases: immunomodulation of neonata dendritic cells. Clin Exp Immunol 2007, 149(2):344-352.

84. Latvala S, Pietila TE, Veckman V, Kekkonen RA, Tynkkynen S, Korpela R, Julkunen I: Potentially probiotic bacteria induce efficient maturation but differential cytokine production in human monocyte-derived dendritic cells. World J Gastroenterol 2008, 14(36):5570-5583, discussion 5581-5572.

85. Kwon HK, Lee CG, So JS, Chae CS, Hwang JS, Sahoo A, Nam JH, Rhee JH, Hwang KC, Im SH: Generation of regulatory dendritic cells and CD4 +Foxp3+ T cells by probiotics administration suppresses immune disorders. Proc Natl Acad Sci U S A 2010, 107(5):2159-2164.

86. Denou E, Pridmore RD, Berger B, Panoff JM, Arigoni F, Brussow H: Identification of genes associated with the long-gut-persistence phenotype of the probiotic Lactobacillus johnsonii strain NCC533 using a combination of genomics and transcriptome analysis. J Bacteriol 2008, 190(9):3161-3168.

87. Marco ML, Peters TH, Bongers RS, Molenaar D, van Hemert S, Sonnenburg JL, Gordon Jl, Kleerebezem M: Lifestyle of Lactobacillus plantarum in the mouse caecum. Environ Microbiol 2009, 11(10):2747-2757.

88. Lakhdari O, Cultrone A, Tap J, Gloux K, Bernard F, Ehrlich SD, Lefevre F, Dore J, Blottiere HM: Functional metagenomics: a high throughput screening method to decipher microbiota-driven NF-kappaB modulation in the human gut. PLoS One 2010, 5(9)

89. Fero M, Pogliano K: Automated quantitative live cell fluorescence microscopy. Cold Spring Harb Perspect Biol 2010, 2(8):a000455.

90. Coombes $J$, Maloy $\mathrm{KJ}$ : Control of intestinal homeostasis by regulatory $\mathrm{T}$ cells and dendritic cells. Semin Immunol 2007, 19(2):116-126.

91. Bogunovic M, Ginhoux F, Helft J, Shang L, Hashimoto D, Greter M, Liu K, Jakubzick C, Ingersoll MA, Leboeuf M, et al: Origin of the lamina propria dendritic cell network. Immunity 2009, 31(3):513-525.

92. Varol C, Vallon-Eberhard A, Elinav E, Aychek T, Shapira Y, Luche H, Fehling HJ, Hardt WD, Shakhar G, Jung S: Intestinal lamina propria dendritic cell subsets have different origin and functions. Immunity 2009, 31(3):502-512.

93. Rimoldi M, Chieppa M, Salucci V, Avogadri F, Sonzogni A, Sampietro GM, Nespoli A, Viale G, Allavena P, Rescigno M: Intestinal immune homeostasis is regulated by the crosstalk between epithelial cells and dendritic cells. Nat Immunol 2005, 6(5):507-514.

94. Iliev ID, Mileti E, Matteoli G, Chieppa M, Rescigno M: Intestinal epithelial cells promote colitis-protective regulatory T-cell differentiation through dendritic cell conditioning. Mucosal Immunol 2009, 2(4):340-350.

95. Munn DH, Mellor AL: Indoleamine 2,3-dioxygenase and tumor-induced tolerance. J Clin Invest 2007, 117(5):1147-1154.

96. Atuma C, Strugala V, Allen A, Holm L: The adherent gastrointestinal mucus gel layer: thickness and physical state in vivo. Am J Physiol Gastrointest Liver Physiol 2001, 280(5):G922-929.

97. Johansson ME, Phillipson M, Petersson J, Velcich A, Holm L, Hansson GC: The inner of the two Muc2 mucin-dependent mucus layers in colon is devoid of bacteria. Proc Natl Acad Sci U S A 2008, 105(39):15064-15069.

98. Troost FJ, van Baarlen P, Lindsey P, Kodde A, de Vos WM, Kleerebezem M, Brummer RJ: Identification of the transcriptional response of human intestinal mucosa to Lactobacillus plantarum WCFS1 in vivo. BMC Genomics 2008, 9:374.

99. van Baarlen P, Troost FJ, van Hemert S, van der Meer C, de Vos WM, de Groot PJ, Hooiveld GJ, Brummer RJ, Kleerebezem M: Differential NF-kappaB pathways induction by Lactobacillus plantarum in the duodenum of healthy humans correlating with immune tolerance. Proc Natl Acad Sci U S A 2009, 106(7):2371-2376.

100. van Baarlen P, Troost F, van der Meer C, Hooiveld G, Boekschoten M, Brummer RJ, Kleerebezem M: Human mucosal in vivo transcriptome responses to three lactobacilli indicate how probiotics may modulate human cellular pathways. Proc Natl Acad Sci U S A 2011, 108(Suppl 1):4562-4569.

101. Isolauri E, Joensuu J, Suomalainen H, Luomala M, Vesikari T: Improved immunogenicity of oral $\mathrm{D} \times \mathrm{RRV}$ reassortant rotavirus vaccine by Lactobacillus casei GG. Vaccine 1995, 13(3):310-312.

102. de Vrese M, Rautenberg P, Laue C, Koopmans M, Herremans T, Schrezenmeir J: Probiotic bacteria stimulate virus-specific neutralizing antibodies following a booster polio vaccination. Eur J Nutr 2005, 44(7):406-413.

103. Paineau D, Carcano D, Leyer G, Darquy S, Alyanakian MA, Simoneau G, Bergmann JF, Brassart D, Bornet F, Ouwehand AC: Effects of seven potential probiotic strains on specific immune responses in healthy adults: a double-blind, randomized, controlled trial. FEMS Immunol Med Microbiol 2008, 53(1):107-113.

104. Kobayashi N, Saito T, Uematsu T, Kishi K, Toba M, Kohda N, Suzuki T: Oral administration of heat-killed Lactobacillus pentosus strain b240 augments protection against influenza virus infection in mice. Int Immunopharmacol 2011, 11(2):199-203.

105. Kotani Y, Shinkai S, Okamatsu H, Toba M, Ogawa K, Yoshida H, Fukaya T, Fujiwara Y, Chaves PH, Kakumoto K, et al: Oral intake of Lactobacillus pentosus strain b240 accelerates salivary immunoglobulin A secretion in the elderly: A randomized, placebo-controlled, double-blind trial. Immun Ageing 2010, 7:11.

106. Wells JM, Mercenier A: Mucosal delivery of therapeutic and prophylactic molecules using lactic acid bacteria. Nat Rev Microbiol 2008, 6(5):349-362

107. Lykova EA, Vorob'ev AA, Bokovoi AG, Pobedinskaia IN, Gevondian VS, Gevondian NM, Mitrokhin SD, Minaev VI, Dzis NB, Makkaveeva LF, et al: 
[Disruption of microbiocenosis of the large intestine and the immune and interferon status in children with bacterial complications of acute viral infections of the respiratory tract and their correction by high doses of bifidumbacterin forte]. Antibiot Khimioter 2000, 45(10):22-27.

108. Davidson LE, Fiorino AM, Snydman DR, Hibberd PL: Lactobacillus GG as an immune adjuvant for live-attenuated influenza vaccine in healthy adults: a randomized double-blind placebo-controlled trial. Eur J Clin Nutr 2011, 65(4):501-507.

109. Cario E, Gerken G, Podolsky DK: Toll-like receptor 2 enhances ZO-1associated intestinal epithelial barrier integrity via protein kinase $C$. Gastroenterology 2004, 127(1):224-238.

110. Rakoff-Nahoum S, Paglino J, Eslami-Varzaneh F, Edberg S, Medzhitov R: Recognition of commensal microflora by toll-like receptors is required for intestinal homeostasis. Cell 2004, 118(2):229-241.

111. Wells JM, Konstaninov S, Konings I, Karczewski J: Effects of probiotic and commensals on epithelial barrier function. International Journal of Probiotics and Prebiotics. International Journal of Probiotics and Prebiotics 2008, 3(3):127-132.

112. Ulluwishewa D, Anderson RC, McNabb WC, Moughan PJ, Wells JM, Roy NC: Regulation of Tight Junction Permeability by Intestinal Bacteria and Dietary Components. J Nutr 2011.

113. Qin H, Zhang Z, Hang X, Jiang Y: L. plantarum prevents enteroinvasive Escherichia coli-induced tight junction proteins changes in intestinal epithelial cells. BMC Microbiol 2009, 9:63.

114. Anderson RC, Cookson AL, McNabb WC, Park Z, McCann MJ, Kelly WJ, Roy NC: Lactobacillus plantarum MB452 enhances the function of the intestinal barrier by increasing the expression levels of genes involved in tight junction formation. BMC Microbiol 2010, 10:316.

115. Mangell $P$, Nejdfors $P$, Wang $M$, Ahrne S, Westrom B, Thorlacius $H$, Jeppsson B: Lactobacillus plantarum 299v inhibits Escherichia coliinduced intestinal permeability. Dig Dis Sci 2002, 47(3):511-516.

116. Resta-Lenert S, Barrett KE: Probiotics and commensals reverse TNF-alphaand IFN-gamma-induced dysfunction in human intestinal epithelial cells. Gastroenterology 2006, 130(3):731-746.

117. Mao Y, Nobaek S, Kasravi B, Adawi D, Stenram U, Molin G, Jeppsson B: The effects of Lactobacillus strains and oat fiber on methotrexate-induced enterocolitis in rats. Gastroenterology 1996, 111(2):334-344.

118. White JS, Hoper M, Parks RW, Clements WD, Diamond T, Bengmark S: The probiotic bacterium Lactobacillus plantarum species 299 reduces intestinal permeability in experimental biliary obstruction. Lett App/ Microbiol 2006, 42(1):19-23.

119. Karczewski J, Troost FJ, Konings I, Dekker J, Kleerebezem M, Brummer RJ, Wells JM: Regulation of human epithelial tight junction proteins by Lactobacillus plantarum in vivo and protective effects on the epithelial barrier. Am J Physiol Gastrointest Liver Physiol 2010, 298(6):G851-859.

120. Seth A, Yan F, Polk DB, Rao RK: Probiotics ameliorate the hydrogen peroxide-induced epithelial barrier disruption by a PKC- and MAP kinase-dependent mechanism. Am J Physiol Gastrointest Liver Physiol 2008, 294(4):G1060-1069.

121. Shen L, Black ED, Witkowski ED, Lencer WI, Guerriero V, Schneeberger EE, Turner JR: Myosin light chain phosphorylation regulates barrier function by remodeling tight junction structure. J Cell Sci 2006, 119(Pt 10):2095-2106.

122. Neish AS, Gewirtz AT, Zeng H, Young AN, Hobert ME, Karmali V, Rao AS, Madara JL: Prokaryotic regulation of epithelial responses by inhibition of IkappaB-alpha ubiquitination. Science 2000, 289(5484):1560-1563.

doi:10.1186/1475-2859-10-S1-S17

Cite this article as: Wells: Immunomodulatory mechanisms of lactobacilli. Microbial Cell Factories 2011 10(Suppl 1):S17.

\section{Submit your next manuscript to BioMed Central and take full advantage of:}

- Convenient online submission

- Thorough peer review

- No space constraints or color figure charges

- Immediate publication on acceptance

- Inclusion in PubMed, CAS, Scopus and Google Scholar

- Research which is freely available for redistribution

Submit your manuscript at www.biomedcentral.com/submit 